\title{
Physiology and Pathology of Host Immune Responses to Exogenous and Endogenous Murine Retroviruses - From Gene Fragments to Epitopes -
}

\author{
Masaaki Miyazawa and Ryuichi Fujisawa \\ Department of Pathology, Tohoku University School of \\ Medicine, Sendai 980-77
}

\begin{abstract}
Miyazawa, M. and Fujisawa, R. Physiology and Pathology of Host Immune Responees to Exogenous and Endogenous Murine Retroviruses - From Gene Fragments to Epitopes. Tohoku J. Exp. Med., 1994, 173 (1), 91-103 — Spontaneous and induced immunity against exogenous Friend murine leukemia retrovirus infection is controlled by four H-2-linked host genes and a single non-H-2 gene. Recognition of the envelope glycoprotein gp70 of Friend virus by helper T cells is restricted by $\mathrm{A}^{\mathrm{b}}$ and hybrid $\mathrm{E}^{\mathrm{b} / \mathrm{k}(\mathrm{d})}$ class II MHC molecules. By expressing portions of the $e n v$ gene and by utilizing synthetic oligopeptides, an $\mathrm{A}^{\mathrm{b}}$-restricted and a hybrid $\mathrm{E}^{\mathrm{b} / \mathrm{d}}$-restricted helper $\mathrm{T}$ cell epitopes were identified in the $\mathrm{N}$-and C-terminal portions of gp70, respectively. These epitopes differ in their amino acid sequences from the previously reported endogenous retroviral peptides naturally presented by mouse MHC class II molecules. Possible roles of recombinant polytropic viruses in the induction of autoimmune responses against endogenous retroviral antigens are also discussed. —— retroviruses; endogenous provirus; epitopes; tolerance; autoimmunity
\end{abstract}

Retroviruses contain in each virion particle an RNA-dependent DNA polymerase (reverse transcriptase) which copies the genetic information from a viral RNA genome to a double-stranded DNA. The DNA intermediates of viral replication may then be integrated within the cellular DNA of the infected host as proviruses. Proviral forms of retroviruses are not distinguished from chromosomal DNA of the infected host by cellular machinery of DNA replication, and are transmitted genetically from mother cells to daughter cells through cell division. Endogenous retroviruses are believed to have their origin in exogenous infection of germ cells (Coffin 1982). Proviruses introduced into the germ line are inherited as stable Mendelian genes along with the mutational changes of the chromosomal DNA produced by proviral integration (Frankel et al. 1989; Coffin et al. 1991). Therefore, retroviruses are most threatening to genetic integrity of eukaryotic organisms. It seems logical for this reason that the mammalians have

Address for reprints: Masaaki Miyazawa, Department of Pathology, Tohoku University School of Medicine, 2-1 Seiryo-machi, Aoba-ku, Sendai 980-77, Japan. 
acquired genes that confer spontaneous resistance against exogenous retrovirus infection. Restriction of exogenous retrovirus infection by host resistance mechanisms has best studied in mice using rapidly-transforming acute leukemia viruses, especially the Friend murine leukemia virus complex (FV) (Teich et al. 1982; Chesebro et al. 1990). Thus, several host genes controlling the susceptibility to FV-induced acute erythroleukemia have been identified. Although their mechanisms of action are not thoroughly understood, some restrict infectious entry of ecotropic murine leukemia viruses $(\mathrm{MuLV})$ by blocking the cell surface receptors (Ikeda and Odaka 1983), others restrict viral replication at steps between virus entry and proviral integration (Jolicoeur and Rassart 1980; Yang et al. 1980), and still other host genes control proliferation of the target cells of infection (Hoatlin et al. 1990). In addition to the genes that directly control virus replication in the target cells, other genes influence host immune responses to viral antigens and/or virus-infected host cells, and thereby control infectious entry and replication of retroviruses indirectly in the infected host body. In this review, we start with the description of these physiolgical or protective immune responses against exogenous retrovirus infection, and then turn to the discussion of pathological immune responses to endogenous retroviruses, which sometimes result in autoimmune diseases.

\section{Friend murine leukemia retrovirus complex and acute erythroleukemia}

FV is an exogeneus retrovirus complex composed of replication-competent ecotropic Friend murine leukemia helper virus (F-MuLV) and acutely transforming, defective spleen focus-forming virus (SFFV) (Fig. 1). F-MuLV can replicate by itself in mouse cells, but usually does not induce leukemia when inoculated into adult mice. On the other hand, the complex of F-MuLV and SFFV can induce rapid polyclonal proliferation of immature erythroblasts in infected adult mice, which leads to acute splenomegaly within a few days after inoculation. This polyclonal proliferation of erythroblasts is caused and can be reproduced in vitro by infection with SFFV alone. The product of SFFV env gene, gp55, is responsible for the continuous growth stimulation of erythroblasts through the binding to the erythropoietin receptor ( $\mathrm{Li}$ et al. 1990). In some strains of mice, malignant transformation of proliferating erythroblasts occurs, and results in the emergence of monoclonal erythroleukemia which causes the late stage of Friend disease, fatal leukemic splenomegaly, at around one month after inoculation. Leukemic mice die between one and three months after infection. Repeated infection of helper F-MuLV to the expanded population of erythroblasts and integration of the proviruses in or around cellular oncogenes or antioncogenes seem to play important roles in inducing the monoclonal stage (Ikawa et al. 1992).

When inoculated into newborn mice retroviruses without transforming genes, including $\mathrm{F}-\mathrm{MuLV}$, may induce leukemia after a long incubation period. This is analogous to spontaneous lymphomas and/or leukemias associated with the 


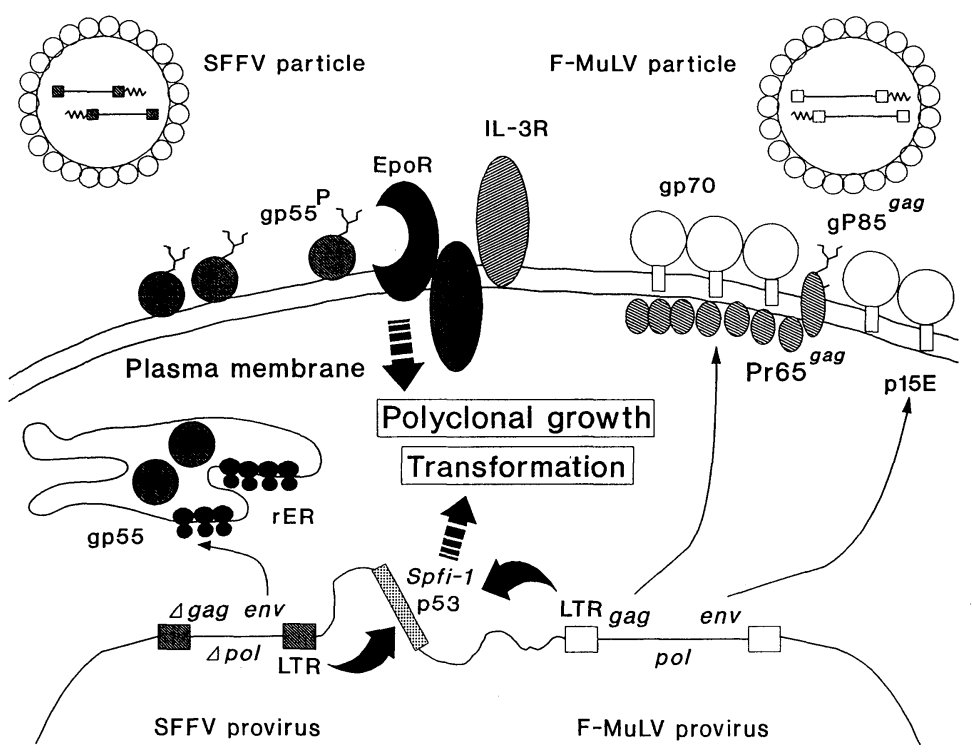

Fig. 1. Friend murine leukemia retrovius complex and its mechanism of leukemia induction. EpoR, erythropoietin receptor; IL-3R, interleukin-3 receptor; gp55, SFFV env gene product; gp55 ${ }^{\mathrm{P}}$, glycosylated form of gp55 expressed on the infected cell surface; $\mathrm{rER}$, rough endoplasmic reticulum; Pr65 ${ }^{\mathrm{gag}}$, the precursor to $\mathrm{F}-\mathrm{MuLV}$ core proteins encoded by the gag gene; $\mathrm{gP}^{8} 5^{\text {gag }}$, glycosylated cell-surface polyprotein encoded by the gag gene; p15E, membrane anchor protein encoded by the env gene; Sfpi-1, a cellular oncogene; p53, a tumor suppressor gene; $\Delta$, deleted genes.

expression of infectious endogenous retroviruses in leukemia-prone strains of mice. Both in the spontaneous leukemias associated with the expression of endogenous ecotropic viruses and in leukemias induced after newborn inoculation of replication-competent exogenous $\mathrm{MuLV}$, production of recombinant polytropic viruses play crucial roles in malignant transformation of infected target cells (Teich et al. 1982; Coffin et al. 1991). However, inoculation of exogenous retroviruses into newborn mice induces immunologic tolerance (Chieco-Bianchi et al. 1988; Korostoff et al. 1990), and leukemogenic polytropic viruses have a recombined env gene that encodes an envelope glycoprotein structurally and immunologically different from that of the initially infected exogenous virus. Thus, these slowly induced leukemias are not suitable to study host immune control of viral replication and leukemogenesis. On the other hand, rapid induction of erythroleukemia in immunocompetent adult mice and direct involvement of viral gene products in leukemogenesis make the FV-induced disease ideal for immunologic studies.

To study the influence of host immune responses on incidence and kinetics of leukemogenesis in FV-infected mice, the effects of non-immune host mechanisms 
that restrict the replication of FV components and control erythroblast differentiation must be excluded. Therefore, we used $\mathrm{F}_{1}$ hybrid mice of congenic strains that share the $F v-1^{b / b}$ and $F v-2^{r / s}$ genotypes in combination with a B-tropic strain of FV to ensure that the virus replicates efficiently in the infected host cells and can induce rapid proliferation of erythroblasts. When inoculated with FV, adult mice of some of these congenic strains recover spontaneously from initial development of splenomegaly, and show strong resistance against repeated challenge with FV after the recovery (Lilly 1968; Chesebro et al. 1974). Four genes closely linked to the major histocompatibility complex (H-2) and a single non-H-2 gene influence this spontaneous recovery from FV-induced splenomegaly (Chesebro et al. 1990). At least one resistance allele at the non-H-2 locus, $R f v-3^{r}$, is necessary for spontaneous recovery regardless of $\mathrm{H}-2$ genotypes of the infected mice. This non-H-2 gene controls the production of neutralizing antibodies against $\mathrm{F}-\mathrm{MuLV}$ when mice are inoculated without prior immunization. Mice having a dominant $R f v-3^{r}$ allele clear viremia and virus-producing cells in the spleen within three weeks after FV infection, while mice with the susceptible $R f v-3^{s / s}$ genotype remain viremic even at 60 days after inoculation. Mechanisms by which this non-H-2 gene cotrol the production of F-MuLV-neutralizing antibodies are unknown. However, $R f v-3$ genotypes seem to affect only spontaneous recovery from $\mathrm{FV}$-induced splenomegaly but not the induced immunity against $\mathrm{FV}$ challenge, since $(\mathrm{A} . \mathrm{BY} \times \mathrm{A}) \mathrm{F}_{1} R f v-3^{s / s}$ mice could be protected against $\mathrm{FV}$ infection by immunization with a vaccinia-F-MuLV env recombinant virus (Miyazawa et al., unpublished data).

\section{Influence of $H-2$ genes on spontaneous and induced immunity against $F V$ infec- tion}

When tested in congenic mice of heterzygous $R f v-3^{r / s}$ genotype, genes in the mouse major histocompatibility complex, H-2, show strong influence on spontaneous recovery from $\mathrm{FV}$-induced splenomegaly. $\mathrm{H}-2^{\mathrm{a} / \mathrm{a}}$ and $\mathrm{H}-2^{\mathrm{d} / \mathrm{d}}$ mice are extremely susceptible to FV infection, and do not show any signs of spontaneous recovery even when inoculated with a very low dose of FV. They usually die within 23 months after inoculation, showing massive hepatosplenomegaly and an extremely high hematocrit value. The largest spleen we have encountered in FV-infected leukemic mice weighed nearly $6 \mathrm{~g}$, and spleens of $>4 \mathrm{~g}$ in weight are not rare. On the other hand, mice of homozygous $\mathrm{H}-2^{\mathrm{b} / \mathrm{b}}$ genotype are very resistant to $\mathrm{FV}$ induced splenomegaly. They develop initial splenomegaly due probably to the polyclonal proliferation within 2 to 3 weeks after inoculation. However, most of the mice of this genotype recover spontaneously from the early enlargement of the spleen around 40 days after inoculation, and only a small percentage (usually $<$ $10 \%$ ) of them die by 100 days after inoculation even when infected with a very high dose of 15,000 spleen focus-forming units (SFFU). Interestingly, heterozygous $\mathrm{H}-2^{\mathrm{a} / \mathrm{b}}$ mice lie between the $\mathrm{H}-2^{\mathrm{a} / \mathrm{a}}$ and $\mathrm{H}-2^{\mathrm{b} / \mathrm{b}}$ mice in their ability to 
recover from $\mathrm{FV}$-induced leukemia: when inoculated with a large dose of 1,500 SFFV, nearly all of them develop leukemic splenomegaly and more than half of them die within 3 months after infection, while most mice of the same genotype recover spontaneously from the initial splenomegaly, and only $<20 \%$ die of leukemia when inoculated with a low dose of 15 SFFV.

To map the H-2 genes that influence spontaneous recovery from FV-induced splenomegaly, several strains of recombinant mice that have chromosomal recombinations within the $\mathrm{H}-2$ loci were tested along with a few strains of mutant and transgenic mice. When inoculated with a low dose of $\mathrm{FV}$, four separate genes linked to H-2 influence spontaneous recovery; class II A, class II E, class I D, and class I-related Qa/Tla (Chesebro et al. 1990; Miyazawa et al. 1992a, b; Perry et al. 1994). The effect of the $D$ locus is the strongest and, regardless of their genotypes in other H-2 loci, mice lacking a resistant $D^{b}$ allele showed little signs of recovery from initial splenomegaly even when they were inoculated with a very low dose of FV (Fig. 2). On the other hand, mice having the heterozygous $D^{\text {bld }}$ genotype showed different kinetics of recovery depending on their genotypes in the A locus. Thus, $A^{b / k}, D^{b / d}$ mice recovered from the initial development of splenomegaly

(A)

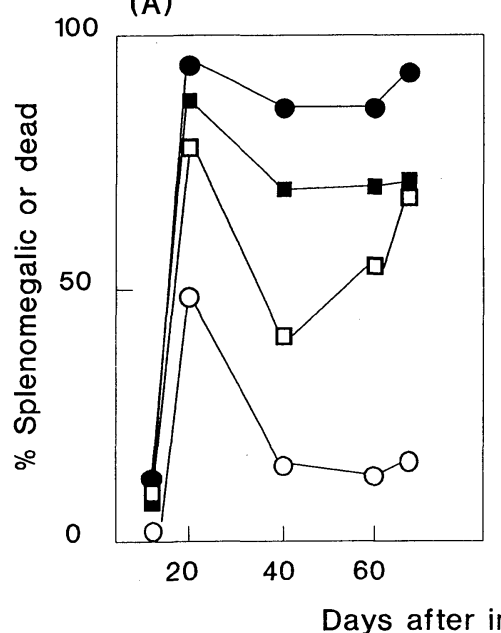

(B)

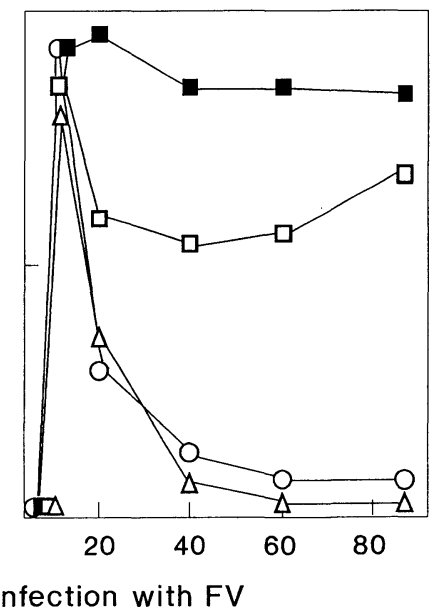

Fig. 2. Kinetics of the development of and spontaneous recovery from FVinduced splenomegaly. A. H-2 recombinant strains of mice having the $(\mathrm{B} 10 \times \mathrm{A}) \mathrm{F}_{1}$ background were inoculated with a low dose of FV. $\bullet,(\mathrm{B} 10$. $\mathrm{A} \times \mathrm{A}) \mathrm{F}_{1}, A^{k / k}, D^{d / d} ;$ O, (B10.A $\left.\times \mathrm{A} . \mathrm{BY}\right) \mathrm{F}_{1}, A^{k / b}, D^{d / b} ; \mathbf{m},(\mathrm{B} 10 . \mathrm{A}(18 \mathrm{R}) \times \mathrm{A})$ $\mathrm{F}_{1}, A^{b / k}, D^{d / d} ; \square,(\mathrm{B} 10 . \mathrm{A}(1 \mathrm{R}, 2 \mathrm{R}$, or $4 \mathrm{R}) \times \mathrm{A}) \mathrm{F}_{1}, A^{k / k}, D^{b / d}$. B. Homozygous $\mathrm{H}-2^{\mathrm{b} / \mathrm{b}}(\mathrm{B} 10 \times \mathrm{A} . \mathrm{BY}) \mathrm{F}_{1}$ mice were inoculated with a high dose of $\mathrm{FV}$. Mice were treated with an anti-CD4 ( $\square$ ), anti-CD8 (匹), or an isotype-matched control antibody $(\triangle)$ for depletion of corresponding T cell subsets in vivo. $O$, mice infected with FV without prior treatment with an antibody. Part B is reproduced from Robertson et al. (1992) with permission. 
when inoculated with a low dose of $\mathrm{FV}$, while $A^{k / k}, \mathrm{D}^{b / d}$ mice relapsed into leukemia after early decrease in the incidence of splenomegaly, and more than half of the mice having the latter genotypes died within three months after inoculation with a low dose of FV (Miyazawa et al. 1992a). These data obtained with the H-2 recombinant mice suggested that spontaneous recovery from FV-induced splenomegaly was mediated by at least two different mechanisms of immunity which were controlled by class II A and class I D loci of the H-2. This interpretation was further supported by an experiment performed by Robertson et al. (1992) in which they depleted $\mathrm{CD} 4^{+}$or $\mathrm{CD}^{+}$population of $\mathrm{T}$ cells in highly resistant $\mathrm{H}-2^{\mathrm{b} / \mathrm{b}}$ mice prior to the administration of FV. Depletion of $\mathrm{CD}^{+} \mathrm{T}$ cells almost completely abolished spontaneous recovery, while mice depleted of $\mathrm{CD} 4^{+} \mathrm{T}$ cells showed initial decrease in the incidence of splenomegaly but relapsed into leukemia by 40 days after inoculation (Fig. 2). Thus, it seems likely that $\mathrm{D}^{\mathrm{b}}$-restricted $\mathrm{CD}^{+} \mathrm{T}$ cells are required for initial recovery from the early stage of splenomegaly, and $\mathrm{A}^{\mathrm{b}}$-restricted $\mathrm{CD} 4^{+} \mathrm{T}$ cells are necessary to maintain the recovered state in the later phase.

The effects of the class II $\mathrm{E}$ and nonclassical class I Qa/Tla loci were weaker, and only detectable when $\mathrm{E}_{\alpha}{ }^{+}$mice were treated with anti-E antibodies or $\mathrm{H}-2$ congenic strains were inoculatd with a low dose of FV (Miyazawa et al. 1992b; Perry et al. 1994). At the class I D locus, two $D^{b}$ alleles are required for full resistance against a high dose of $\mathrm{FV}$, and this gene dose effect explains the difference in susceptibility to FV infection between the homozygous $\mathrm{H}-2^{\mathrm{b} / \mathrm{b}}$ and heterozygous $\mathrm{H}-2^{\mathrm{a} / \mathrm{b}}$ mice (Miyazawa et al. 1992c).

While the $\mathrm{D}$ locus shows the strongest influence on spontaneous recovery from FV-induced leukemia, the presence of at least one $A^{b}$ allele is the sole and indispensable requirement for the induction of protective immunity against FV infection when mice are immunized with a recombinant vaccinia virus that expresses the env gene of F-MuLV. Mice having an $A^{b}$ allele were protected against FV challenge by the envelope-specific priming of helper $\mathrm{T}$ cells regardless of their genotypes in other H-2 loci (Morrison et al. 1987). These results obtained from the spontaneous recovery and immune protection experiments suggest that $\mathrm{CD}^{+}$helper $\mathrm{T}$ cells recognize the $\mathrm{F}-\mathrm{MuLV}$ env gene products in the context of class II $\mathrm{A}^{\mathrm{b}}$ molecules.

\section{Recognition of viral envelope gp 70 by helper $T$ cells}

The mechanisms of the effect of MHC class II genes on $\mathrm{T}$ cell recognition of Friend viral antigens were further studied in antigen-specific proliferation assays. Primed T cells from the heterozygous $\mathrm{H}-2^{\mathrm{a} / \mathrm{b}}$ mice that had been immunized with the recombinant vaccinia virus expressing the $\mathrm{F}-\mathrm{MuLV}$ env gene proliferated significantly only when antigen presenting cells were prepared from the mice having an $A^{b}$ allele (Miyazawa et al. 1988). Antigen presenting cells lacking an $A^{b}$ allele do not stimulate F-MuLV envelope-specific proliferative responses of 
$\mathrm{H}-2^{\mathrm{a} / \mathrm{b}} \mathrm{T}$ cells. Moreover, presentation of the antigen to $\mathrm{H}-2^{\mathrm{a} / \mathrm{b}} \mathrm{T}$ cells that were specifically primed with the vaccinia virus-F-MuLV env recombinant by syngeneic antigen presenting cells was blocked with anti- $\mathrm{A}^{\mathrm{b}}$ monoclonal antibodies. Thus, class II $\mathrm{A}^{\mathrm{b}}$ molecules are directly involved in the presentation of $\mathrm{F}-\mathrm{MuLV}$ envelope antigen to proliferating $\mathrm{T}$ cells. Interestingly, antigen presenting cells that express the mutant $\mathrm{A}^{\mathrm{bm} 12}$ class II molecules instead of $\mathrm{A}^{\mathrm{b}}$ could not present the $\mathrm{F}-\mathrm{MuLV}$ env gene products to specifically primed $\mathrm{H}-2^{\mathrm{a} / \mathrm{b}} \mathrm{T}$ cells, and $\mathrm{T}$ cells prepared from the $\mathrm{H}-2^{\mathrm{a} / \mathrm{bm} 12}$ mice that were immunized with the vaccinia virus-F-MuLV env recombinant did not show significant proliferative responses when stimulated with antigen presenting cells expressing the $\mathrm{A}^{\mathrm{b}}$ or $\mathrm{A}^{\mathrm{bm} 12}$ molecules (Miyazawa et al. 1988). The mutant $\mathrm{A}^{\mathrm{bm} 12}$ class II molecule is different from the wild-type $\mathrm{A}^{\mathrm{b}}$ at only three amino acids in the $\beta_{1}$ exon of the $\mathrm{A} \beta$ chain, and despite their serologic and cellular immunologic difference readily detectable in cross immunization experiments, $\mathrm{H}-2^{\mathrm{bm} 12}$ and $\mathrm{H}-2^{\mathrm{b}}$ mice are not much different in their immune responsiveness to most of the synthetic and natural antigens so far tested (Hansen and Tse 1987). F-MuLV envelope glycoprotein is one of relatively rare examples to which $\mathrm{H}-2^{\mathrm{b}}$ mice are high responders while $\mathrm{H}-2^{\mathrm{bm} 12}$ mice are nonresponders, along with poly $\left(\mathrm{Glu}^{60} \mathrm{Ala}^{40}\right)(\mathrm{GA})$, male-specific histocompatibility antigen $\mathrm{H}-\mathrm{Y}$, and beef insulin. In the cases of the GA polymer and beef insulin, the number of $\mathrm{T}$ cell epitopes are very limited because of their chemical structure (GA) or immunologic tolerance to self antigen (insulin). In fact, both $\mathrm{H}-2^{\mathrm{b}}$ and $\mathrm{H}-2^{\mathrm{bm} 12}$ mice are responders to sheep and horse insulins, and both are nonresponders to pork insulin. Only with beef insulin, the difference in $\mathrm{T}$ cell responsiveness between $\mathrm{H}-2^{\mathrm{b}}$ and $\mathrm{H}-2^{\mathrm{bm12}}$ mice has been observed. It seems that the difference in a single amino acid at position A9 of the insulin $\alpha$ chain is responsible for this difference in $\mathrm{T}$ cell recognition (Hansen and Tse 1987).

The major envelope glycoprotein gp70 encoded by the env gene of MuLV is a fairly complex, large protein composed of more than 450 amino acids and many carbohydrate chains. The fact that the responsiveness of helper $\mathrm{T}$ cells to such a large glycoprotein is different between $\mathrm{H}-2^{\mathrm{b}}$ and $\mathrm{H}-2^{\mathrm{bm} 12}$ mice in a all-or-none fashion is quite surprising, and suggests that the immune system can recognize only a limited number of T cell epitopes on F-MuLV gp70. To actually identify helper $\mathrm{T}$ cell epitopes in F-MuLV gp70, we utillzed several $\mathrm{T}$ helper cell clones specific to an FV-induced tumor cell line, FBL-3, along with a panel of recombinant vaccinia viruses that express portions of the F-MuLV genome (Iwashiro et al. 1993). All the four helper $\mathrm{T}$ cell clones proliferated significantly when stimulated with F-MuLVenv gene products, but not when stimulated with the SFFV env or F-MuLVgag gene products. Using the recombinant vaccinia viruses that express a truncated env gene, $\mathrm{T}$ helper cell epitopes were localized in at least two separate portions in the gp70 envelope protein. By scanning the regions with synthetic peptides, one $\mathrm{A}^{\mathrm{b}}$-restricted helper $\mathrm{T}$ cell epitope in the $\mathrm{N}$-terminal portion and another in the C-terminal portion were identified (Fig. 3). The latter 


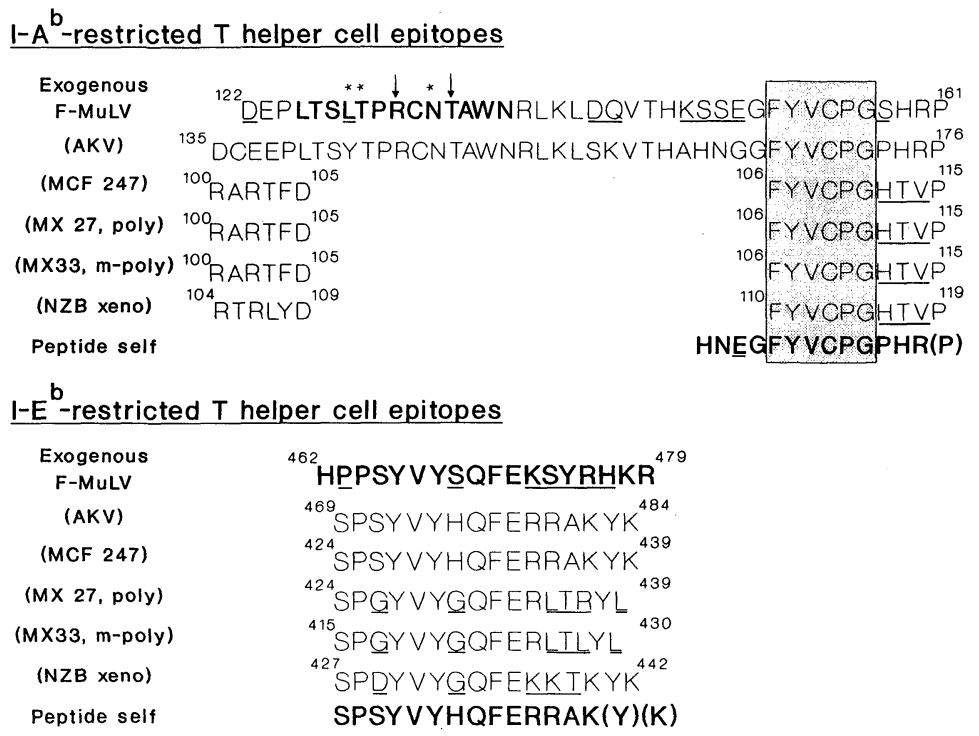

Fig. 3. Amino acid sequence, expressed by the single letter code, of the two helper $\mathrm{T}$ cell epitopes identified in the F-MuLV gp70. Experimentally identified epitopes (Iwashiro et al. 1993) and the endogenous retroviral peptides naturally presented by the class II molecules (Rudensky et al. 1991) are shown in boldface. Amino acid sequences deduced from corresponding regions of the env of representative endogenous retroviruses are also listed for comparison. $\mathrm{AKV}$, an endogenous ecotropic virus encoding the infectious virus in AKR mice; MCF 247, a representative infectious polytropic (mink cell focusinducing) virus; MX 27 and MX 33, representative endogenous polytropic (poly) and modified polytropic (m-poly) proviruses (Stoye and Coffin 1987); NZB xeno, an infectious xenotropic virus, NZB-IU-6, induced from a NZB mouse. Underlined amino acids are different from the corresponding sequence of the AKV env gene product.

epitope was recognized in the context of hybrid $\mathrm{E}^{\mathrm{b} / \mathrm{d}}$ class II molecules. The presence of a third epitope somewhere in the middle of gp70 was also suggested. A synthetic peptide representing the $\mathrm{A}^{\mathrm{b}}$-restricted $\mathrm{N}$-terminal epitope, DEPLTSLTPRCNTAWNRLKL, induced much stronger proliferative responses of both the two helper $\mathrm{T}$ cell clones when presented with the $\mathrm{A}^{\mathrm{b}}$ molecule than when the same peptide was presented with the mutant $\mathrm{A}^{\mathrm{bm} 12}$ molecule. On the other hand, bm12 mutation of the $\mathrm{A}_{\beta}{ }^{\mathrm{b}}$ molecule did not affect the presentation of the $\mathrm{E}^{\mathrm{b} / \mathrm{d}}$-binding C-terminal epitope. These results indicate that the antigenic epitope recognized by the majority of $\mathrm{T}$ helper cells in the mice immunized with the whole gp70 molecule expessed by the vaccinia virus-F-MuLV env is that of the $\mathrm{N}$-terminal, because the responsiveness to the whole molecule is also significantly affected by the bm12 mutation of the H-2 of antigen presenting cells.

In recent years endogenous peptides naturally presented by $\mathrm{MHC}$ molecules 
have been eluted from purified class I and class II MHC molecules and their sequences analyzed. The most surprising but somewhat expected aspect of the identification of these endogenous peptides is that endogenous retrovial env gene-derived peptides represent a significant proportion of the natural ligands presented by the mouse class II molecules (Rudensky et al. 1991). T cells are tolerant to these naturally presented self peptides (Rammensee et al. 1993). Since virtually all strains of mice possess multiple copies of endogenous retroviruses (Frankel et al. 1990; Coffin et al. 1991), it is conceivable that T cells of normal mice are tolerant to retroviral antigenic peptides that share the amino acid sequence with an endogenous retrovirus, provided that the endogenous viral gene products are expressed in a significant amount. This notion is consistent with the above-descrided hypothesis of ours that the number of recognizable T cell epitopes on exogenous F-MuLV is limited due to tolerance to endogenous retroviruses.

The $\mathrm{A}^{\mathrm{b}}$-restricted $\mathrm{N}$-terminal helper $\mathrm{T}$ cell epitope identified in the $\mathrm{F}-\mathrm{MuLV}$ gp70 is located in the insertional sequence which is unique to ecotropic viruses, and the amino acid sequence of the epitope is irrelevant to the endogenous peptide naturally presented by the $\mathrm{A}^{\mathrm{b}}$ molecule (Fig. 3). This N-terminal insertion is absent from env genes of endogenous xenotropic viruses (Khan 1984; O'Neill et al. 1985). In contrast, the endogenous peptide naturally bound to the $\mathrm{A}^{\mathrm{b}}$ molecule is located in the conserved portion of the murine leukemia viral gp70, and a stretch of amino acids in the center of this peptide, FYVCPG, is common to the known molecular clones that represent all the four classes of endogenous retroviruses (Fig. 3). The amino acid sequence of the $\mathrm{E}^{\mathrm{b} / \mathrm{d}}$-restricted C-terminal epitope on F-MuLV gp70 is different from the corresponding endogenous retroviral peptide in 7 of the 16 amino acids (Fig. 3). This relatively small difference in amino acid sequence between the exogenous retroviral helper $\mathrm{T}$ cell epitope and the naturally presented endogenous peptide may explain a weak but consistent self reactivity of the $\mathrm{T}$ cell clone reactive to this epitope (Iwashiro et al. 1993). Thus, it seems very likely that $\mathrm{T}$ cells recognize only those antigenic epitopes on exogenous retroviruses that are structurally different from those of endogenous retroviruses.

\section{Autoimmune responses against endogenous retroviruses}

In some cases antibodies produced against exogenous or endogenous retroviral antigens can cause "autoimmune diseases" (Krieg and Steinberg 1990). We can regard spontaneously produced antibodies against endogenous retroviruses as "autoantibodies," since endogenous retroviruses are inherited as normal Mendelian genes, and the immune system of the host is tolerant to their gene products. In fact, the deposition of endogenous xenotropic viral gp70 molecules has been demonstrated in the glomeruli of $(\mathrm{NZB} \times \mathrm{NZW}) \mathrm{F}_{1}$ mice along with host IgG and C3 (Yoshiki et al. 1974), and the presence of circulating gp70-anti-gp70 immune complexes has been associated with the development of fatal glomerulonephritis 
in the $(\mathrm{NZB} \times \mathrm{NZW}) \mathrm{F}_{1}, \mathrm{MRL} / \mathrm{Mp}-l p r / l p r$ and $\mathrm{BXSB} / \mathrm{Mp}$ mice (Izui et al. 1979). We have also shown that in the $\mathrm{SL} / \mathrm{Ni}$ strain of mice production of antibodies against endogenous ecotropic viral gp70 is associated with the immune destruction of vascular smooth muscle cells, which leads to the development of necrotizing polyarteritis (Miyazawa et al. 1987).

The mechanisms by which the immune system makes antibodies against endogenous retroviral gene products are unknown. However, the expression of infectious or non-infectious recombinant polytropic viruses after the establishment of immunologic tolerance to endogenous retroviral antigens that are expressed earlier in life might play some roles to escape from the tolerance and to stimulate the immune system. Such polytropic viruses are produced through the recombination of genes between infectious endogenous ecotropic viruses and non-infectious endogenous polytropic proviruses (Evans and Malik 1987; Coffin et al. 1991). In mice prone to spontaneous leukemia and/or lymphoma, expression of infectious recombinant polytropic viruses is closely associated with the leukemogenesis. Of course, endogenous polytropic or xenotropic viral env genes are physiologically expressed as differentiation antigens in subsets of hematopoietic cells (Buller et al. 1989). Therefore, the immune system must be tolerant to the products of some, if not all, endogenous polytropic viruses. However, precise timing in the ontogeny and location in the body of the polytropic viral expression, and detailed antigenic properties of the expressed viral proteins have not been analyzed. It must be stressed that such analysis must be done in virus type- and epitope-specific manners. Thus, recombinant polytropic viruses possessing antigenic epitopes which are absent from endogenous polytropic or xenotropic viruses may be produced in the adult life prior to the development of autoimmune diseases. The immune tolerance to the endogenous retroviral antigens might then be bypassed through responsiveness of $\mathrm{T}$ cells to a novel epitope expressed on the recombinant envelope molecule. Such epitopes might exist in the C-terminal portion of the gp70 close to the $\mathrm{E}^{\mathrm{b} / \mathrm{d}}$-restricted epitope of the F-MuLV gp70, and $\mathrm{T}$ cells reacting with that epitope might show a "self reactivity." In this regard, abrogation of the development of glomerulonephritis in the lupus-prone strains of mice by administration of anti-class II antibodies (Adelman et al. 1983) or by introduction of class II $\mathrm{E}_{\alpha}$ gene (Merino et al. 1993) suggest that reactivity of MHC class II-restricted T helper cells to endogenous antigenic peptides do play a crucial role in the development of autoimmune diseases.

\section{References}

1) Adelman, N.E., Watling, D.L. \& McDevitt, H.O. (1983) Treatment of $(\mathrm{NZB} \times \mathrm{NZW})$ $\mathrm{F}_{1}$ disease with anti-I-A monoclonal antibodies. J. Exp. Med., 158, 1350-1355.

2) Buller, R.S., van Zant, G., Eldridge, P.W. \& Portis, J.L. (1989) A population of murine hematopoietic progenitors express an endogenous retroviral gp70 linked to the $R m c f$ gene and associated with resistance to erythroleukemia. J. Exp. Med., 169, 865-880. 
3) Chesebro, B., Wehrly, K. \& Stimpfling, J. (1974) Host genetic control of recovery from Friend leukemia virus-induced splenomegaly: Mapping of a gene within the major histocompatibility complex. J. Exp. Med., 140, 1457-1467.

4) Chesebro, B., Miyazawa, M. \& Britt, W.J. (1990) Host genetic control of spontaneous and induced immunity to Friend murine retrovirus infection. Annu. Rev. Immunol., 8, 477-499.

5) Chieco-Bianchi, L., Collavo, D. \& Biasi, G. (1988) Immunologic unresponsiveness to murine leukemia virus antigens: Mechanisms and role in tumor development. $A d v$. Cancer Res., 51, 277-306.

6) Coffin, J. (1982) Endogenous viruses. In: RNA Tumor Viruses. Molecular Biology of Tumor Viruses, 2nd edition, edited by R. Weiss, N. Teich, H. Vermus \& J. Coffin, Cold Spring Harbor Laboratory, Cold Spring Harbor, N. Y., pp. 1109-1203.

7) Coffin, J., Stoye, J.P. \& Frankel, W.N. (1991) Endogenous murine retroviruses and leukemia. In: Viruses That Affect the Immune System, edited by H.Y. Fan, I.S. Chen, N. Rosenberg \& W. Sugden, American Society for Microbiology, Washington, D.C. pp. 175-191.

8) Evans, L.H. \& Malik, F.G. (1987) Class II polytropic murine leukemia viruses (MuLVs) of $\mathrm{AKR} / \mathrm{J}$ mice: Possible role in the generation of class I oncogenic polytropic MuLVs. J. Virol., 61, 1882-1892.

9) Frankel, W.N., Stoye, J.P., Taylor, B.A. \& Coffin, J.M. (1989) Genetic analysis of endogenous xenotropic murine retroviruses: Association with two common mouse mutations and the viral resistance locus Fv-1. J. Virol., 63, 1763-1774.

10) Frankel, W.N., Stoye, J.P., Taylor, B.A. \& Coffin, J.M. (1990) A linkage map of endogenous murine leukemia proviruses. Genetics, 124, 221-236.

11) Hansen, T.H. \& Tse, H.Y. (1987) Insights into immune-response gene function using an Ia mutant mouse strain. CRC Crit. Rev. Immunol., 7, 169-191.

12) Hoatlin, M. E., Kozak, S. L., Lilly, F., Chakrabarti, A., Kozak, C. A. \& Kabat, D. (1990) Activation of erythropoietin receptors by Friend viral gp55 and by erythropoietin and down-regulation by the murine $\mathrm{Fv}-2^{r}$ resistance gene. Proc. Natl. Acad. Sci. USA, 87, 9985-9989.

13) Ikawa, Y., Suda, Y., Furuta, Y., Tsukada, T., Takai, S. \& Aizawa, S. (1992) Search for genes cooperating with SFFV-gp55 transgene in Friend erythroleukemia development. In: Molecular Approaches to the Study and Treatment of Human Disease. edited by T.O. Yoshida \& J.M. Wilson, Elsevier Science Publishers B.V., Amsterdam, pp. 229-237.

14) Ikeda, H. \& Odaka, T. (1983) Cellular expression of murine leukemia virus gp70related antigen on thymocytes of uninfected mice correlates with $F v-4$ gene-controlled resistance to Friend leukemia virus infection. Virology, 128, 127-139.

15) Iwashiro, M., Kondo, T., Shimizu, T., Yamagishi, H., Takahashi, K., Matsubayashi, Y., Masuda, T., Otaka, A., Fujii, N., Ishimoto, A., Miyazawa, M., Robertson, M.N., Chesebro, B. \& Kuribayashi, K. (1993) Multiplicity of virus-encoded helper T cell epitopes expressed on FBL-3 tumor cells. J. Virol., 67, 4533-4542.

16) Izui, S., McConahey, P.J., Theofilopoulos, A.N. \& Dixon, F.J. (1979) Association of circulating retroviral gp70-anti-gp70 immune complexes with murine systemic lupus erythematosus. J. Exp. Med., 149, 1099-1116.

17) Jolicoeur, P. \& Rassart, E. (1980) Effect of $F v-1$ gene product on synthesis of linear and supercoiled viral DNA in cells infected with murine leukemia virus. J. Virol., 33, 183-195.

18) Khan, A.S. (1984) Nucleotide sequence analysis etablishes the role of endogenous murine leukemia virus DNA segments in formation of recombinant mink cell focusforming murine leukemia virus. J. Virol., 50, 864-871.

19) Korostoff, J.M., Nakada, M.T., Faas, S.J., Blank, K.J. \& Gaulton, G.N. (1990) Neonatal exposure to thymotropic Gross murine leukemia virus induces virus-specific 
immunologic nonresponsiveness. J. Exp. Med., 172, 1765-1775.

20) Krieg, A.M. \& Steinberg, A.D. (1990) Retroviruses and autoimmunity. J. Autoimmun., 3, 137-166.

21) Li, J-P., D'Andrea, A.D., Lodish, H.F. \& Baltimore, D. (1990) Activation of growth by binding of Friend spleen focus-forming virus gp55 glycoprotein to the erythropoietin receptor. Nature, 343, 762-764.

22) Lilly, F. (1968) The effect of histocompatibility-2 type on response to the Friend leukemia virus in mice. J. Exp. Med., 127, 465-473.

23) Merino, R., Iwamoto, M., Fassati, L., Muniesa, P., Araki, K., Takahashi, S., Huarte, J., Yamamura, K.-I., Vassalli, J.-D. \& Izui, S. (1993) Prevention of systemic lupus erythematosus in autoimmune BXSB mice by a transgene encoding I-E $\alpha$ chain. $J$. Exp. Med., 178, 1189-1197.

24) Miyazawa, M., Nose, M., Kawashima, M. \& Kyogoku, M. (1987) Pathogenesis of arteritis of SL/Ni mice. Possible lytic effect of anti-gp70 antibodies on vascular smooth muscle cells. J. Exp. Med., 166, 890-908.

25) Miyazawa, M., Nishio, J. \& Chesebro, B. (1988) Genetic control of T cell responsiveness to the Friend murine leukemia virus envelope antigen: Identification of class II loci of the H-2 as immune response genes. J. Exp. Med., 168, 1587-1605.

26) Miyazawa, M., Nishio, J., Wehrly, K. \& Chesebro, B. (1992a) Influence of MHC genes on spontaneous recovery from Friend retrovirus-induced leukemia. J. Immunol., 148, 644-647.

27) Miyazawa, M., Nishio, J., Wehrly, K., David, C.S. \& Chesegro, B. (1992b) Spontaneous recovery from Friend retrovirus-induced leukemia: Mapping of the $R f v-2$ gene in the Q/TL region of mouse MHC. J. Immunol., 148, 1964-1967.

28) Miyazawa, M., Nishio, J., Wahrly, K., Jay, G., Melvold, R.W. \& Chesebro, B. (1992c) Detailed mapping of the $R f v-1$ gene that influences spontaneous recovery from Friend retrovirus-induced leukemia. Eur. J. Immunogenet., 19, 159-164.

29) Morrison, R.P., Earl, P. L., Nishio, J., Lodmell, D.L., Moss, B. \& Chesebro, B. (1987) Different H-2 subregions influence immunization against retrovirus and immunosuppression. Nature, 329, 729-732.

30) O'Neill, R.R., Buckler, D.E., Theodore, T.S., Martin, M. \& Repaske, R. (1985) Envelope and long terminal repeat sequence of cloned infectious NZB xenotropic murine leukemia virus. J. Virol., 53, 100-106.

31) Perry, L.L., Miyazawa, M., Hasenkrug, K., Wehrly, K., David, C.S. \& Chesebro, B. (1994) Contrasting effects from a single major histocompatibility complex class II molecule $(H-2 E)$ in recovery from Friend virus leukemia. J. Virol., 68, 4921-4926.

32) Rammensee, H.-G., Falk, K. \& Rötzschke, O. (1993) Peptides naturally presented by MHC class I molecules. Annu. Rev. Immunol., 11, 213-244.

33) Robertson, M.N., Spangrude, G.J., Hasenkrug, K., Perry, L., Nishio, J., Wehrly, K. \& Chesebro, B. (1992) Role and specificity of T-cell subsets in spontaneous recovery from Friend virus-induced leukemia in mice. J. Virol., 66, 3271-3277.

34) Rudensky, A.Y., Preston-Hurlburt, P., Hong, S.-C., Barlow, A. \& Jeneway, C.A. (1991) Sequence analysis of peptides bound to MHC class II molecules. Nature, 353, 622-627.

35) Stoye, J.P. \& Coffin, J.M. (1987) The four classes of endogenous murine leukemia viruses: Structural relationships and potential for recombination. J. Virol., 61, 26592669.

36) Teich, N., Wyke, J., Mak, T., Bernstein, A. \& Hardy, W. (1982) Pathogenesis of retrovirus-induced disease. In: RNA Tumor Viruses. Molecular Biology of Tumor Viruses, 2nd edition, edited by R. Weiss, N. Teich, H. Vermus \& J. Coffin, Cold Spring Harbor Laboratory, Cold Spring Harbor, N.Y. pp. 785-998.

37) Yang, W.K., Kiggans, J.O., Yang, D.-M., Ou, C.-Y., Tennant, R.W., Brown, A. \& Bassin, R.H. (1980) Synthesis and circularization of N- and B-tropic retroviral DNA 
in Fv-1 permissive and restrictive mouse cells. Proc. Natl. Acad. Sci. USA, 77, 2994-2998.

38) Yoshiki, T., Mellors, R.C., Strand, M. \& August, J.T. (1974) The viral envelope glycoprotein of murine leukemia virus and the pathogenesis of immune complex glomerulonephritis of New Zealand mice. J. Exp. Med., 140, 1011-1027. 